\title{
Improving digital tools for Quaternary field survey: a case study of the Rodoretto Valley (NW Italy)
}

\author{
Maria Gabriella Forno • Andrea Lingua • \\ Stefano Lo Russo • Glenda Taddia
}

Received: 28 April 2010/Accepted: 9 February 2011/Published online: 1 March 2011

(C) Springer-Verlag 2011

\begin{abstract}
In the modern geological mapping activities geomatics technologies can facilitate data collection during field survey and avoid practical problems related to the transposition of that data onto topographic maps. This paper describes an innovative tool (the Solid True OrthoPhoto; STOP) for the structured acquisition and recording of geological field survey data that is immediately available in a GIS framework. An experimental software graphical interface has been developed to manage the STOP application during the survey. The benefits of the STOP system were tested by producing a digital map of the Quaternary formations and landforms in a $3-\mathrm{km}^{2}$ sector of the Rodoretto Valley, a minor tributary of the Germanasca Valley, northwestern Italy.
\end{abstract}

Keywords Geological field survey · Quaternary · Solid True OrthoPhoto · GIS · Piedmont · Italy

\section{Introduction}

Technological innovations in recent times have given a new dimension for understanding the environmental problems of the earth. A system of geospatial technologies has been developed, which is the combination of remote sensing, geographical information systems (GIS), global

M. G. Forno

Department of Earth Sciences, Università degli Studi di Torino, Via Valperga Caluso, 35, 10125 Turin, Italy

\section{A. Lingua $\cdot$ S. Lo Russo $(\bowtie) \cdot$ G. Taddia}

Department of Land, Environment and Geo-Engineering

(DITAG), Politecnico di Torino, C.so Duca degli Abruzzi 24, 10129 Turin, Italy

e-mail: stefano.lorusso@polito.it positioning systems (GPS) and spatial modelling which are found to be effective tools in offering solutions to many problems related to land surface and its management (Joseph et al. 2010). The improvements accomplished in spatial, spectral, temporal and radiometric resolutions of remote sensing data over the past few decades have kept pace with the information needs for the management of several geological and environmental problems such as floods and landslides risk assessment, air, soil and water pollution, forest and agricultural development (Akgun and Türk 2010; Drolet et al. 2005; Joseph et al. 2010; Oh et al. 2010; Poudyal et al. 2010). The GIS software packages have also been developed rapidly to accommodate large data files and, therefore, larger data on geographical areas, multiple spatial and non-spatial data integration and analysis, and the incorporation of complex geo-statistical tools. With all these developments, the role geoinformatics in assessing and monitoring the landscape turn out to be more effective, scientific, realistic and economical than conventional tools. Also, it has opened up new ways of analyzing and monitoring several phenomena potentially dangerous for the human development and the environmental sustainability (Fernandes-da-Silva et al. 2010; Goyal et al. 2010; Jia et al. 2006; Varghese and Murthy 2006).

On the other hand, the survey performed directly on the ground continues to maintain a vital role both for the correct understanding of the phenomena analyzed and for monitoring the effectiveness of techniques for remote investigation. The improvement of techniques for the ground survey is therefore an important goal for geoinformatics, especially for what concerns the correct geolocation of information gathered on the land and the interoperability of GIS systems. These improvements appear particularly important in the geological survey aimed at the production of geological maps. 
A geological map can present many types of information at different levels of detail; a basic map records the distribution of rocks and landforms in a given area and may be key for the evaluation of the area's geological history. Geological maps may be used for a wide range of purposes, such as the identification of groundwater resources and potential geological hazards, the prediction of foundation and slope stability problems, and the selection of locations for agricultural activities (Assaad et al. 2004).

The production of a geological map integrates directly collected field survey data with aerial photography interpretation and/or remote sensing analysis (Compton 1985; Groshong 1999; Gupta 2003; Manning 2007; Walsh et al. 1998). GIS are used to overlay maps and other forms of information for simultaneous digital viewing (Gao 2008; Litwin and Andreychouk 2008; Siart et al. 2009). Printed geological maps can be produced with a GIS layout.

Several well-structured field campaigns are usually required for the production of a reliable geological map. Good organization is important from the preliminary phase of map production through the integration of survey data with other (remote) geological information sources (Bocco et al. 2001). Several practical problems can arise during field surveys, particularly during the transposition of survey data onto topographic maps. The geometrical structures and relationships of geological bodies and visible landforms (e.g., outcrops, faults, tectonic contacts, scarps) can be incorrectly plotted, especially if the available map is outdated or insufficiently detailed. Structural measures or sampling points can also be erroneously plotted if the surveyor's position is not precisely determined. Portable instruments such as GPS and laser distance meters can reduce such errors.

The Solid True OrthoPhoto (STOP) system was developed by Dequal and Lingua (2003) to address and minimize the difficulties and sources of inaccuracy encountered during field surveys. Respect the more traditional tools, the main innovation of STOP is represented by the availability and the integration on a user-friendly unified software platform of: (i) complete 3-D land data set, and (ii) correct aerial photographic information in a geo-referenced form directly on-site during the survey. In fact, without using STOP, these data may be actually used only in a partial and not integrated way during the laboratory post-processing phases of the map production. Therefore, the availability of STOP on a tablet PC permits the surveyor to acquire directly on the field the geological information in a more rapid, comprehensive and accurate way.

This case report tested the characteristics of STOP during several field campaigns. The application was used to produce a detailed reconstruction of Quaternary evolution and a detailed geologic map in a mountainous area of the Rodoretto Basin (Germanasca Valley, northwestern Italy).
Drawing on this experience, the potentials and limitations of STOP for geological field survey are discussed.

\section{Methods}

\section{Solid True OrthoPhoto properties}

A digital orthophoto is a geometrically corrected photographic representation of a territory. It has the same accuracy as a traditional topographic map (Krauss 2004) but contains much more information, such as aerial photographic details. Whether natural or human-modified, a territory is realistically represented without the codes or symbology used in digital map production. Each pixel of an aerial image is orthogonally projected onto a cartographic plane, producing a geometrically correct map. The orthophoto functions like a traditional map; angles, distances and coordinates can be read and measured. While the correct interpretation of a digital map requires technical training, an unskilled user can correctly read and understand an orthophoto.

Orthophotos may be employed in land-planning applications such as infrastructural planning, land-use monitoring, and geological mapping. In fact, through the ortho-photo it is possible to recognize and interpret in a 2-D way several geological details clearly detectable at different viewing scales. Adding 3-D information by means of a dense digital surface model (DDSM) it is possible to enhance the quality of the geological information surveying to optimize the understanding of the geo-phenomena and their timeevolution.

Difficulties may be encountered, however, where land surfaces are characterized by discontinuities and hidden areas. Commercially available software may be insufficient for the production of an acceptable orthophoto in these situations (Krauss 2004), and DDSM, acquired for example with light detection and ranging (LiDAR) techniques (Dequal and Lingua 2003), becomes necessary.

A true orthophoto can be displayed, analyzed and queued in a georeferenced manner using GIS software (Fig. 1). The height values derived from the DDSM can be merged with the orthophoto to create the ortho solid image, a simple extension of the three-dimensional (3D) solid image (Bornaz and Dequal 2003). For each pixel of an ortho solid image, it is possible to record (Fig. 2):

- three color values for the red-green-blue (RGB) color image extracted from the orthophoto (3 bytes);

- one height value derived from the DDSM and recorded as integer*2 (FORTRAN variable type, integer 2 bytes) or a real*4 (FORTRAN variable type, float 4 bytes).

If the height is expressed in centimeters, 2 bytes can represent a value between -327.67 and $+327.68 \mathrm{~m}$. $66 \%$ 


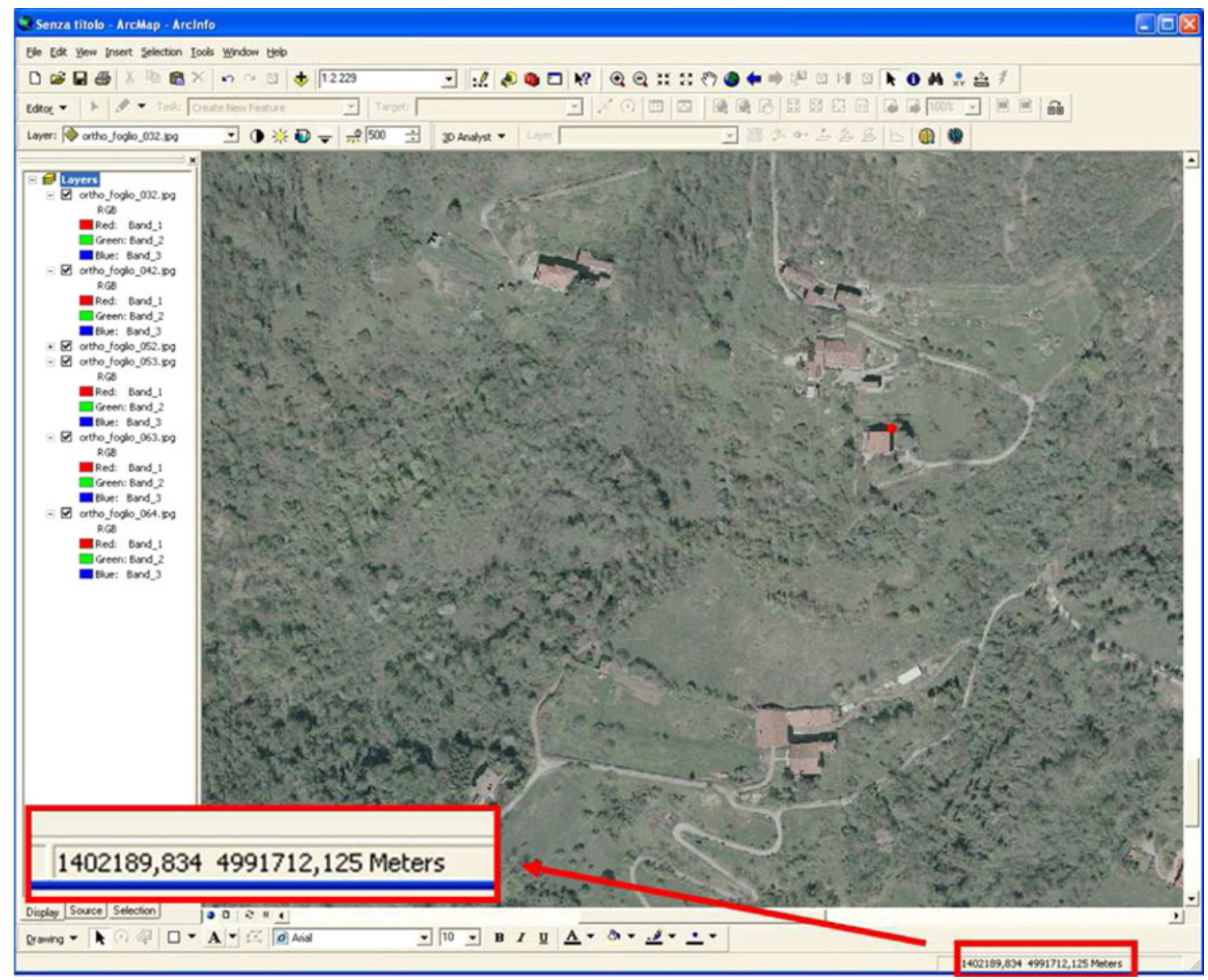

Fig. 1 A GIS visualization of orthophoto images

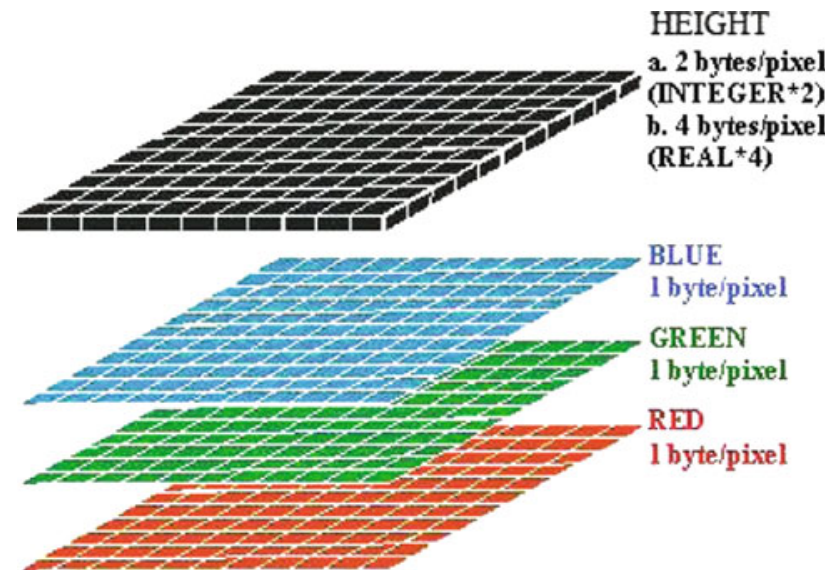

Fig. 2 The structure of a STOP

more memory is required to store an ortho solid image than to store a simple orthophoto. If the considered heights are greater than these limits, 4 bytes can be used to represent any value in floating point format (up to $9999.99 \mathrm{~m}$ ).

The resulting STOP files allow the user to easily and rapidly extract $3 \mathrm{D}$ information in a defined coordinate system. In particular, the true orthophoto is memorized as a digital georeferenced image using world file (TIF + TFW, $\mathrm{BMP}+\mathrm{BPW}, \mathrm{JPG}+\mathrm{JGW}, \ldots)$ : this file contains the 6 parameters $\left(a_{1}, a_{2}, a_{3}, a_{4}, a_{5}, a_{6}\right)$ of an affine transformation that permit to convert the pixel coordinates $(c, r)$ in image system ( $c=$ column, $r=$ row) in his $2 \mathrm{D}$ map coordinates $(x, y)$. Then, the selection of a single pixel from the true orthophoto image matrix in a location $(c, r)$ allows to calculate its 2D map coordinates according to:

$x=a_{1} c+a_{2} r+a_{3}$
$y=a_{4} c+a_{5} r+a_{6}$

A DDSM is given in form of two-dimensional matrix $q(c, r)$ with:

- grid size equal to pixel size of orthophoto;

- numbers of rows and columns correspondent to orthophoto image matrix;

- coincident position of the DDSM grid nodes with the center of the pixel of the orthophotos image.

Then, the choice of the position of the pixel in the orthophoto $(c, r)$ allows to extract the height $q(c, r)$ of the 
terrain surface into the same position. It is possible to also determine the third coordinate adding to the Eq. 1 a very simple equation, getting the fundamental relationships of the STOP:

$$
\begin{aligned}
& x=a_{1} c+a_{2} r+a_{3} \\
& y=a_{4} c+a_{5} r+a_{6} \\
& z=q(c, r)
\end{aligned}
$$

Then the STOP users observe the true orthophotos image, they can choose the pixel that interests them and to get the 3 map coordinates of the $3 \mathrm{D}$ position of selected detail.

An experimental software tool has been developed in Visual Fortran (with version 7.0 GINO and GINOMENU graphic libraries) to manage the STOP application (Lingua et al. 2007). This user interface includes simple query functions, zoom and pan functions, a 3D coordinate viewer, and the ability to take some measurements (e.g., angles, 3D distances, areas, volumes). These features are useful during geological field survey. An apposite command (a) (Fig. 3) prompts STOP to directly calculate (with a least squares procedure) and record dip and dip directions of planes using the $3 \mathrm{D}$ coordinates of their surface points (b); to extract the intersection between planes and the land surface (c); and to define complex volume calculations by the intersection of the topographic surface with several planes (d).

When STOP is uploaded on a commercially available tablet PC, the interface will permit the use of an electronic pen to directly map geological features in the field. STOP thus replaces the traditional topographic map. An integrated portable GPS helps determine the surveyor's position. A field survey utilizing STOP therefore has several advantages over traditional geological field survey techniques:

(1) all collected data are automatically georeferenced in 3D space;

(2) measurements (e.g., angles, 3D distances, areas, volumes, orientations of planes and lines) are easily calculated and automatically stored for subsequent processing and analysis (e.g., pole plots, frequency histograms);

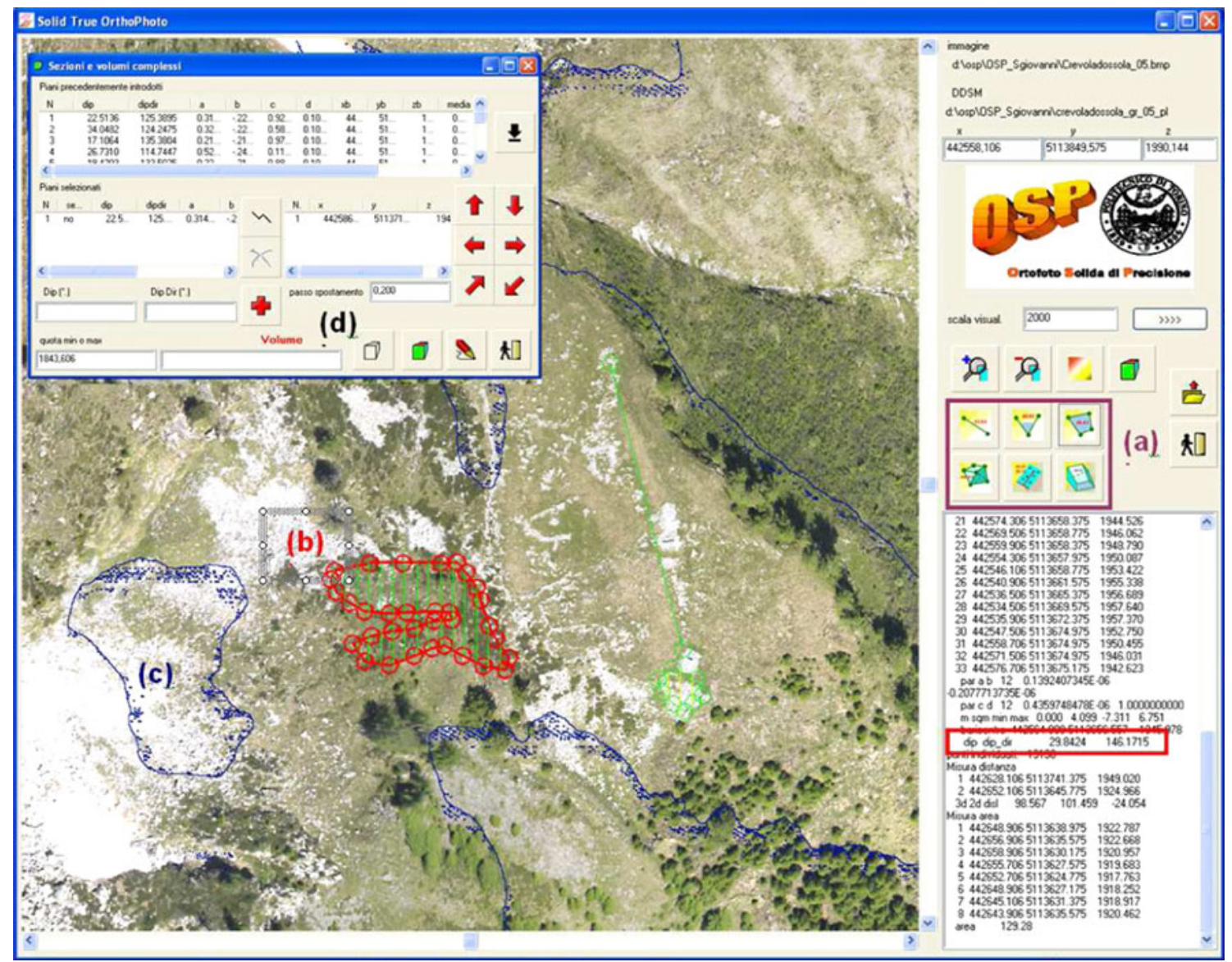

Fig. 3 A representative ortho solid image: $(a)$ measurement tools, $(b)$ dip and dip direction definition, $(c)$ intersection between plane and land surface, $(d)$ complex volume calculation 
(3) topographic sections can be directly produced;

(4) sub-vertical outcrops and landforms such as scarps and ridges are clearly detectable;

(5) a digital map of the investigated area (with contour lines) is always available on the tablet PC screen.

\section{STOP production}

The STOP of this area was produced using the following data provided by the government of Turin Province:

- a true orthophoto with 50-cm ground sample distance (GSD) generated from a set of images acquired by a digital aerial mapping camera (DMC by Zeiss/ Intergraph);

- a DDSM with 1-m GSD generated from aerial LiDAR data $\left(2\right.$ points $\left./ \mathrm{m}^{2}\right)$ by means of geometric regularization, filtering and resampling.

With these data, no further (expensive) data acquisition operations were required.

A professional user skilled in geomatics produced the STOP in $2 \mathrm{~h}$.

The test site: the Rodoretto Valley (Germanasca Valley)

The STOP application was tested by producing a digital map of the Quaternary formations and landforms in a $3-\mathrm{km}^{2}$ sector of the alpine Rodoretto Valley, a tributary of the Germanasca Valley (northwestern Italy). The Germanasca Valley is located along the north-south tectonic thrust between the Dora Maira Massif, which outcrops on the valley's right side, and the greenstone and schist complex visible on its left side (Compagnoni and Hirajima 2001; Sandrone et al. 1993). These nappe systems include the Pennidic Domain (Lower, Medium and Upper Pennidic units) and the Piemontese zone (Compagnoni 2003). The Dora Maira Massif is constituted primarily of garnet micaschists with chloritoid and blue-green amphiboles. The greenstone and schist complex is a metamorphic system with Jurassic marine sediment protoliths. The more diffuse lithotypes are schists, quartz schists, prasinites, and serpentinites (Borghi et al. 1984) (Fig. 4).

The visible landforms and Quaternary sediments in this valley have resulted from the complex effects of alpine glacial phases and gravitative deformations. The production of the geological map thus focused on the relationships among the landforms and sedimentary bodies that developed during this period of the valley's evolution.

\section{Results and discussion}

Quaternary formations

The area of investigation was subdivided into four sectors to facilitate map production and sediment description: the Rodoretto Valley floor (A), and the Punta Acuta (B), Colle di Rodoretto (C), and Passo della Capra (D) left tributary basins (Fig. 4). The sector boundaries marked the main morphological divisions corresponding to glacial phases (Fig. 5).

The primary evidence for glacial activity consisted of glacial cirques recognized in the upper altitudes (2600-2900 m asl altimetric band) of the left tributary basins. They exhibited NNW exposures and had average diameters of 300-400 m. Some "roches moutonnée," or subglacial sediments, were locally preserved on the cirque thresholds.

Silty-sand subglacial sediments with rounded boulders represented the relics of the main glacial valley floor throughout sector A and in the lower portion of sector D. In the northern part of sector $\mathrm{A}$, these sediments were overlaid by organic, planar-bedded, silty, lacustrine deposits.

Lateral and frontal morainic ridges (Fig. 6), comprised primarily of coarse-grained flowtill sediments with decimetric to metric angular clasts, prevailed in the valley floor (sector $\mathrm{A}$ ) and were present in the middle portions of the tributary basins (sectors B and C). These height differences were interpreted as evidence for the complex evolution of the valley during glacial phases. Traces of spillway channels were preserved among the morainic ridges in sectors B and $\mathrm{C}$.

Landslides were extensively distributed in the lower portions of sectors $\mathrm{B}$ and $\mathrm{C}$ and the upper portion of sector $\mathrm{D}$. The major scarps $(10-50 \mathrm{~m}$ high) were predominantly subcircular in shape. Distances between the main crowns and the foot varied from 76-460 $\mathrm{m}$ in sector $\mathrm{D}$ to $300-350 \mathrm{~m}$ in sectors B and C. Paleochannel relicts (1-10 m deep) were recognizable in the main landslide bodies of sectors $\mathrm{B}$ and $\mathrm{C}$. The main stretches were oriented N50-70 in sectors B and C and N140-150 in sector D (Fig. 7).

A deep-seated gravitational slope deformation extended across sectors $\mathrm{C}$ and $\mathrm{D}$, affecting the bedrock schists and the Quaternary cover. Open bedrock fractures were very diffuse, mainly occurring in the upper altitudes of the tributary basins. Tensional trenches were more frequent, primarily affecting Quaternary deposits in the medium and lower altitudes of all sectors. These trenches were 1-10 m in depth and hundreds of meters in length. The fractures and trenches trended predominantly N50-70 and N140-150. Alluvial fans connected to torrential and avalanche phenomena were present in sectors A, B, and C. 
Fig. 4 Quaternary map of the Rodoretto Valley in the Germanasca Valley. 1: bedrock (greenstone schist complex); 2: subglacial sediments; 3: glacial till; 4: landslide main bodies; 5 : rockfall main bodies; 6 : debris flow and avalanche sediments; 7: lacustrine sediments; 8 : glacial cirques; 9: roche moutonnée; 10: morainic ridges; 11: glacial spillway channels; 12: landslide crowns; 13: minor scarps; 14: deep-seated gravitational slope doubled ridges; 15: linear trenches; 16: open tension cracks

[(a) principal, (b) minor]; 17: alluvial and avalanche fans; 18 : paleochannels [(a) principal, (b) minor]; 19: groundwater springs; 20: geographical reference point $\left(44^{\circ} 53^{\prime} 53.84^{\prime \prime} \mathrm{N}\right.$, $\left.7^{\circ} 00^{\prime} 46.33^{\prime \prime} \mathrm{E}\right) ; A, B, C, D$ : sectors (see text)

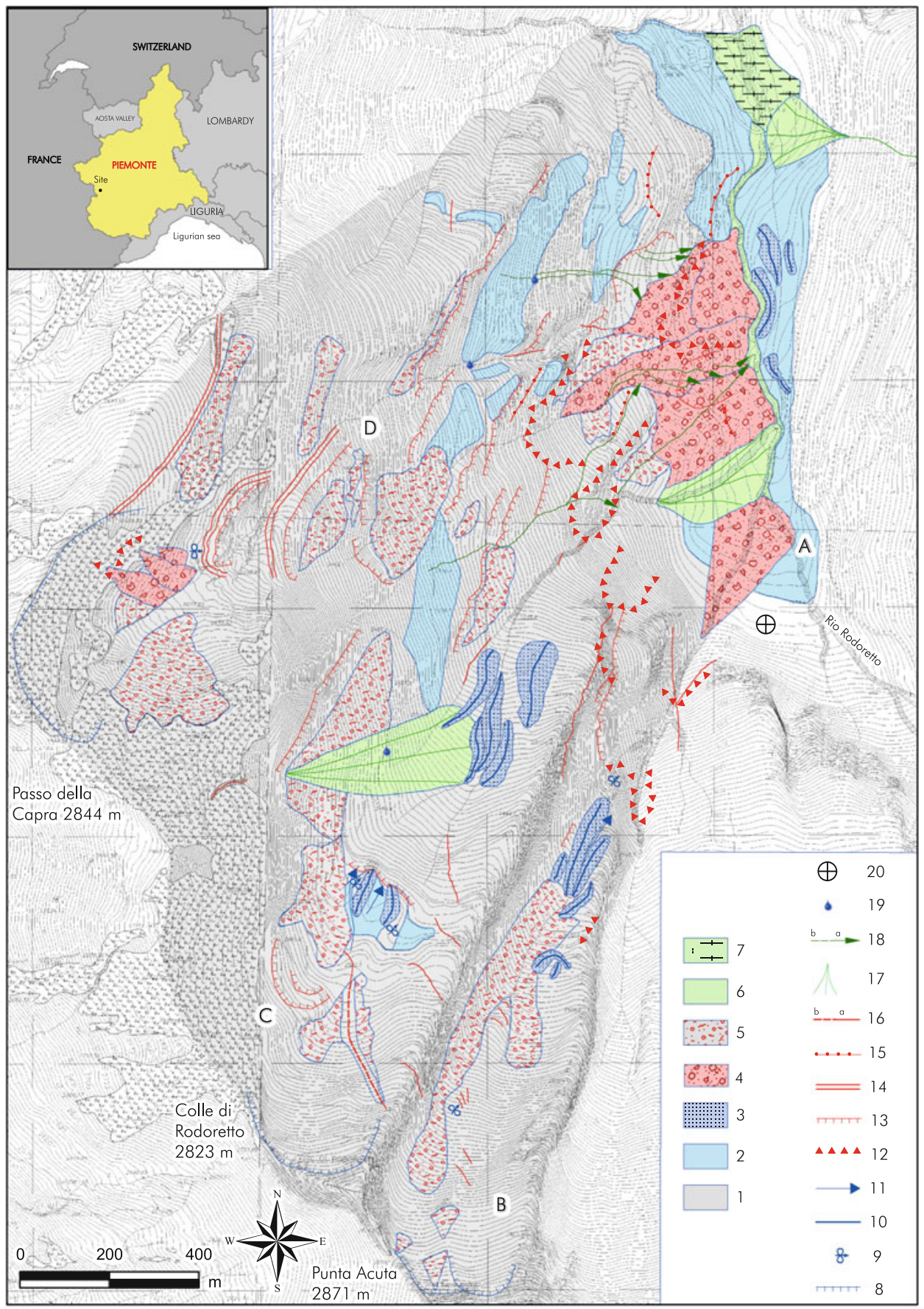

\section{STOP field surveys}

The STOP application was easy to use in the field and allowed significantly less time to be spent on final map production. In fact, the user-friendly interface of viewer tools allows the surveyors to use STOP data with a very short period of laboratory training (1-2 h). Then, during the field activity, the surveyors can be easily visualized and manage STOP to:
- interpret more properly the geologic details using a 3D photographic representation and not a simple topographic map;

- correctly locate with a more reliable accuracy the surveyed geologic particulars and plot them with a predefined geological symbols code directly on the tablet PC.

These practical advantages save time during the field survey that could be estimated between 30 and 50\% with 


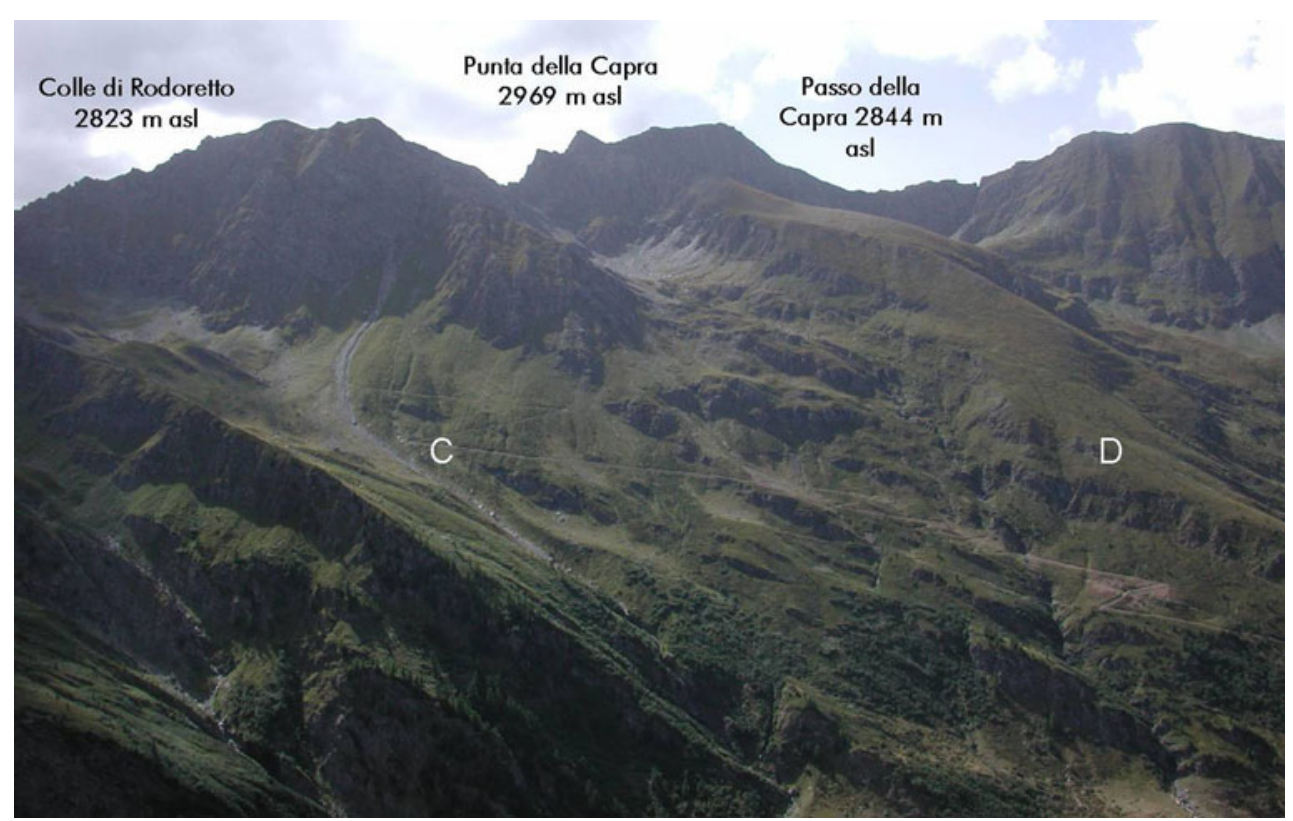

Fig. 5 Colle di Rodoretto and Punta Capra left tributary basins

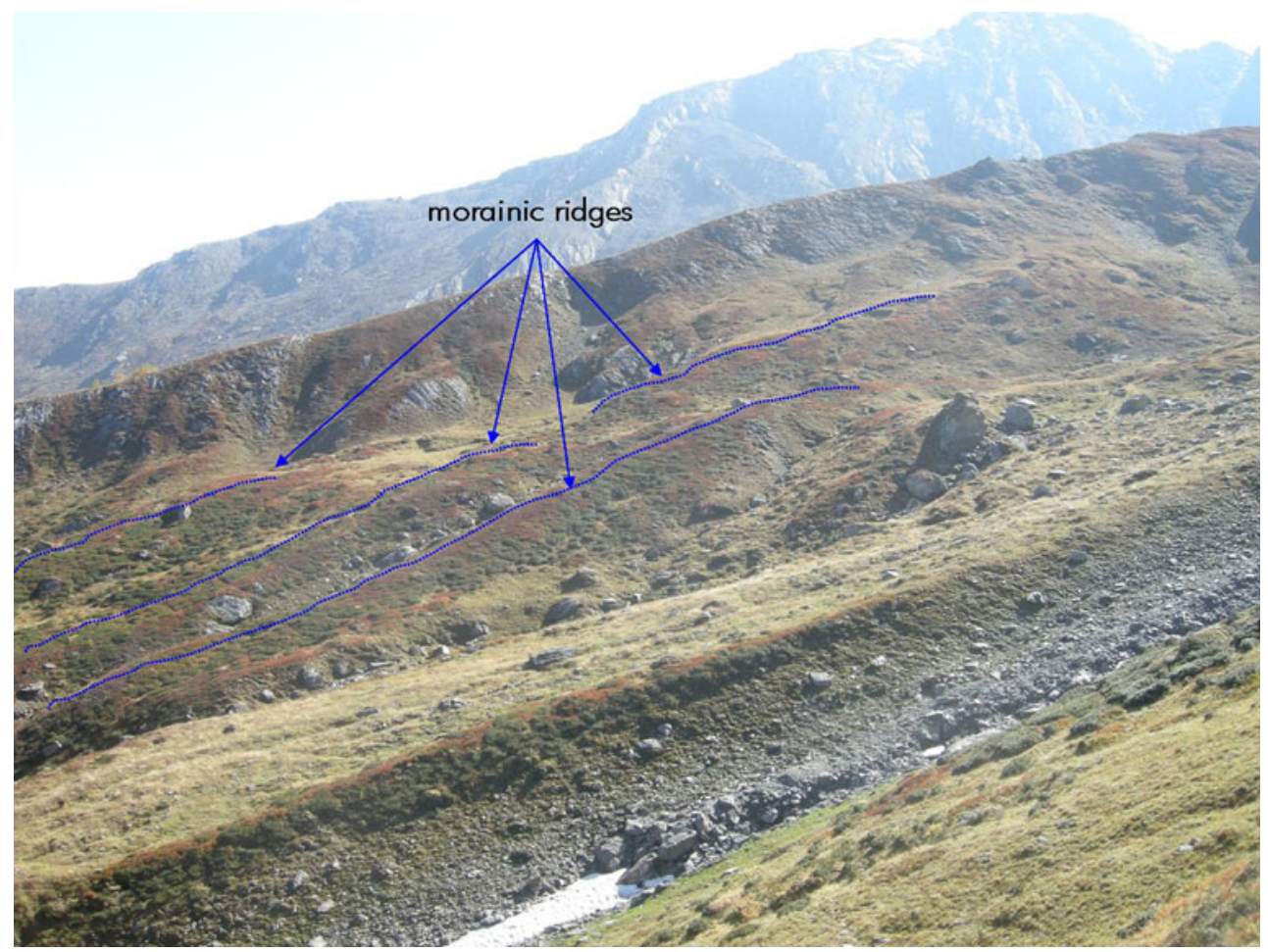

Fig. 6 Morainic ridges in the sector $\mathrm{C}$ basin

respect to the traditional geologic survey techniques (e.g. GPS, map sheets and colored pencils). Moreover, the direct plotting of the Quaternary formations and landforms on the tablet PC during the field survey produced georeferenced data with correct coding that could be automatically processed through a GIS platform. Therefore, the overall time required to produce the final geological map can be further limited during the post-processing phases.

A final map was then produced in the desired layout (Fig. 4). 


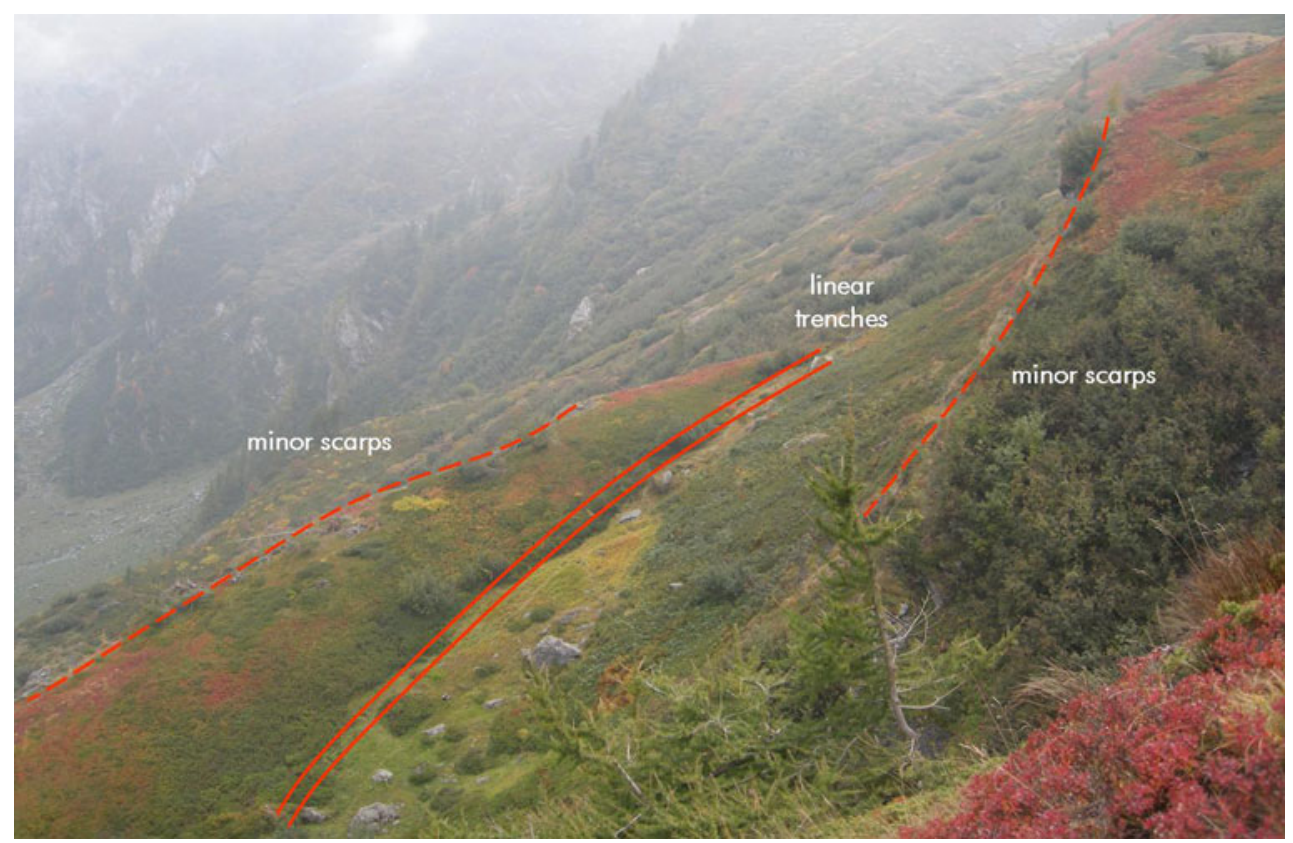

Fig. 7 Linear trenches in the sector D basin

The main limitation encountered during the field survey was the lack of 3D stereoscopic visualization, which produced some difficulty in the identification of subtler relict landforms. This problem was easily overcome in a laboratory setting by viewing the stereoscopic model in a $3 \mathrm{D}$ window using a digital photogrammetric stereoplotting system.

Field surveys involved two geologists for 5 days. Laboratory activity was 2 days long.

\section{Conclusions}

A new, detailed geological map of the Rodoretto Valley Quaternary cover was produced. The investigation recorded previously unmapped glacial tributary evidence, such as lateral and frontal morainic ridges, and outwash incisions connected to small local Pleistocene glaciers. A wide, deep-seated gravitational slope deformation was also defined. This feature formed many trenches of various sizes, doubled ridges, and slide scarps.

Geologists unskilled in geomatics have efficiently used the STOP viewer on a tablet PC during field surveys. The 3D visualization tools offered by the STOP viewer software facilitate the immediate interpretation of relict landforms.

\section{References}

Akgun A, Türk N (2010) Landslide susceptibility mapping for Ayvalik (Western Turkey) and its vicinity by multicriteria decision analysis. Environ Earth Sci. doi:10.1007/s12665-009-0373-1
Assaad F, Lamoreaux PE, Travis H, Hughes TH (2004) Field methods for geologists and hydrogeologists. Springer, Berlin, pp 31-49 ISBN 3-540-40882-7

Bocco G, Mendoza M, Velàzquez A (2001) Remote sensing and GISbased regional geomorphological mapping - a tool for land use planning in developing countries. Geomorphology 39:211-219

Borghi A, Cadoppi P, Porro A, Sacchi R, Sandrone R (1984) Osservazioni geologiche nella Val Germanasca e nella media Val Chisone (Alpi Cozie). Boll Mus Reg Sc Nat Torino 2(2):503-526 (In Italian)

Bornaz L, Dequal S (2003) The solid image: an easy and complete way to describe $3 \mathrm{~d}$ objects-ISPRS COMMISSION V, WG V/2, Ancona, Italy

Compagnoni R (2003) HP metamorphic belt of the western Alps. Episodes 26(3):200-204

Compagnoni R, Hirajima T (2001) Superzoned garnets in the coesitebearing Brossasco-Inasca Unit, Dora Maira massif, Western Alps, and the origin of the whiteschists. Lithos 57:219-236

Compton RR (1985) Geology in the field. Wiley, New York, pp 34-46

Dequal S, Lingua A (2003) True orthophoto of the whole town of Turin. Int Arch Photogram Remote Sens XXXIV-5/C15:263268 ISSN: 1682-1750

Drolet GG, Huemmrich KF, Hall FG, Middleton EM, Black TA, Barr AG, Margolis HA (2005) A MODIS-derived photochemical reflectance index to detect inter-annual variations in the photosynthetic light-use efficiency of a boreal deciduous forest. Remote Sens Environ 98(2-3):212-224

Fernandes-da-Silva PC, Vedovello R, Jose Ferreira C, Canning Cripps J, Brollo MJ, Joao Fernandes A (2010) Geo-environmental mapping using physiographic analysis: constraints on the evaluation of land instability and groundwater pollution hazards in the Metropolitan District of Campinas. Brazil Environ Earth Sci 61:1657-1675. doi:10.1007/s12665-010-0480-z

Gao Y (2008) Spatial operations in a GIS-based karst feature database. Environ Geol 54:1017-1027. doi:10.1007/s00254-0070896-2

Goyal SK, Chaudhary BS, Singh O, Sethi GK, Thakur PK (2010) GIS based spatial distribution mapping and suitability evaluation of 
groundwater quality for domestic and agricultural purpose in Kaithal district, Haryana state, India. Environ Earth Sci 61:1587-1597. doi:10.1007/s12665-010-0472-z

Groshong RH Jr (1999) 3-D structural geology—a practical guide to subsurface map interpretation. Springer-Verlag, Berlin, pp 1-32, $39-50$

Gupta R (2003) Remote sensing geology. Springer, Berlin, 655 pp. ISBN 3-540-43185-3

Jia GJ, Burke IC, Goetz AFH, Kaufmann MR, Kindel BC (2006) Assessing spatial patterns of forest fuel using AVIRIS data. Remote Sens Environ 102:318-327

Joseph S, Murthy MSR, Thomas AP (2010) The progress on remote sensing technology in identifying tropical forest degradation: a synthesis of the present knowledge and future perspectives. Environ Earth Sci. doi:10.1007/s12665-010-0893-8

Krauss K (2004) Photogrammetrie, Band 1. Walter de Gruyter, pp 410-444. ISBN 3-11-017708-0

Lingua A, Agosto E, Del Bianco P (2007). L'ortofoto solida di precisione a grandissima scala in ambito urbano. In: CD Proceedings of XI national conference ASITA. Torino, Italy. ISBN 978-88-903132-0-2 (in Italian)

Litwin L, Andreychouk V (2008) Characteristics of high-mountain karst based on GIS and Remote Sensing. Environ Geol 54:979-994. doi:10.1007/s00254-007-0893-5

Manning J (2007) Remote sensing for terrain analysis of linear infrastructure projects. In: Teeuw R (ed) Mapping hazardous terrain using remote sensing, special publications vol 283. Geological Society, London, pp 135-142

Oh H, Lee S, Soedradjat GM (2010) Quantitative landslide susceptibility mapping at Pemalang area, Indonesia. Environ Earth Sci 60:1317-1328. doi:10.1007/s12665-009-0272-5

Poudyal CP, Chang C, Oh HJ, Lee S (2010) Landslide susceptibility maps comparing frequency ratio and artificial neural networks: a case study from the Nepal Himalaya. Environ Earth Sci. doi: 10.1007/s12665-009-0426-5

Sandrone R, Cadoppi P, Sacchi R, Vialon P (1993) Pre-mesozoic geology in the Alps. In: Von Raumer JF, Neubaur F (eds) The Dora-Maira Massif. Springer Verlag, Berlin

Siart C, Bubenzer O, Eitel B (2009) Combining digital elevation data (SRTM/ASTER), high resolution satellite imagery (Quickbird) and GIS for geomorphological mapping: a multi-component case study on Mediterranean karst in Central Crete. Geomorphology 112(1-2):106-121. doi:10.1016/j.geomorph.2009.05.010

Varghese AO, Murthy YVNK (2006) Application of geoinformatics for conservation and management of rare and threatened plant species. Curr Sci 91:762-769

Walsh S, Butler D, Malanson G (1998) An overview of scale, pattern, process relationships in geomorphology: a remote sensing and GIS perspective. Geomorphology 21:183-205 